\title{
Inhibitory effect and mechanism of action of tanshinone IIA on human bladder cancer cell J82
}

\author{
Xianjun Zhang, Ziwen Lu, Songzhe Piao, Tao Hong* \\ Department of Urology, Taizhou Hospital of Zhejiang Province, Wenzhou Medical University, Linhai, Zhejiang Province, PR \\ China \\ *For correspondence: Email: taohongtz@aliyun.com
}

\begin{abstract}
Purpose: To investigate the therapeutic influence of tanshinone IIA on human bladder cancer cell J82, and the possible signal route involved.

Methods: Cell proliferative potential was measured using MTT assay, while the expressions of associated genes were determined by quantitative reverse transcription-polymerase chain reaction ( $(\mathrm{R} T-P C R)$ and immunoblot assays.

Results: Tanshinone IIA decreased 382 cell survival rate by $>42 \%$ and inactivated apoptosis by suppressing PI3K/AKT/mTOR signal route. Moreover, it decreased Bcl-2, but upregulated caspase and $\operatorname{Bax}(p<0.05)$.

Conclusion: The inhibitory effect of TIIA on human bladder cancer suggests that TIIA can be developed into an anti-tumor agent.
\end{abstract}

Keywords: Tanshinone IIA, Human bladder cancer cell J82, Caspase-3

\begin{abstract}
This is an Open Access article that uses a fund-ing model which does not charge readers or their institutions for access and distributed under the terms of the Creative Commons Attribution License (http://creativecommons.org/licenses/by/4.0) and the Budapest Open Access Initiative (http://www.budapestopenaccessinitiative.org/read), which permit unrestricted use, distribution, and reproduction in any medium, provided the original work is properly credited.

Tropical Journal of Pharmaceutical Research is indexed by Science Citation Index (SciSearch), Scopus, International Pharmaceutical Abstract, Chemical Abstracts, Embase, Index Copernicus, EBSCO, African Index Medicus, JournalSeek, Journal Citation Reports/Science Edition, Directory of Open Access Journals (DOAJ), African Journal Online, Bioline International, Open-J-Gate and Pharmacy Abstracts
\end{abstract}

\section{INTRODUCTION}

Salvia miltiorrhiza is a rich source of the diterpenoid quinone tanshinone 11A (T11A) [1]. Studies have shown that T11A is effective in the management of various cerebrovascular and cardiovascular ailments [2-4]. Recent investigations have further revealed that tanshinones have antitumor [5], antioxidant [6], and anti-inflammatory properties [7]. Urothelial bladder carcinoma (UBC) is the most frequently occurring cancer of the urinogenital system [8]. It has been reported that the management of most UBCs involves surgery and intravesical chemotherapy [9]. Bladder carcinoma is the $6^{\text {th }}$ most common malignancy in men, and the most frequent urologic cancer $[10,11]$. Recently, there has been a steady upsurge in cases of bladder carcinoma in China [11]. This study was focused on the anticarcinogenic influence of TIIA on human bladder cancer cell J82, and to unravel the possible underlying mechanism.

\section{EXPERIMENTAL}

\section{Cell line, media and T11A}

Tanshinone IIA (T11A) was purchased from AmyJet Scientific Company. Its purity was 98.6 $\%$. Human bladder cancer cell J82 was kindly 
obtained from Shanghai Huiying Biological Technology Co. Ltd. The J82 cells were maintained in RPMI-1640 containing $10 \%$ FBS, streptomycin (1\%) and penicillin (1\%).

\section{Cytotoxicity of tanshinone IIA}

The test for cytotoxic effect of T11A on J82 cells was done using MTT method. The cells were seeded in a 96-well plate at a density of $4 \times 10^{3}$ cells/well, and were exposed for $48 \mathrm{~h}$ to graded doses of T11A ranging from 10 to $80 \mu \mathrm{g} / \mathrm{mL}$ ). Thereafter, MTT $(500 \mu \mathrm{g} / \mathrm{mL})$ was added to each well, followed by incubation at $37^{\circ} \mathrm{C}$ for $4 \mathrm{~h}$. Then, the MTT was replaced with $120 \mu \mathrm{L}$ DMSO. The absorbance of the formazan solution was measured spectrophotometrically at $570 \mathrm{~nm}$, and the values obtained were used for computing the inhibition of cell growth.

\section{Immunoblotting}

Following lysis of the cells with protease suppressor-containing RIPA buffer, the protein content of the lysate was assayed with BCA method. Then, $30 \mu \mathrm{g}$ protein samples were resolved on SDS-PAGE, followed by transfer to PVDF which was subsequently blocked by incubation for $1 \mathrm{~h}$ with $5 \%$ de-fatted milk solution in TBST. This was followed by incubation of the membrane overnight with $1^{\circ}$ antibodies for $p$ AKT, p-PI3K, and p-mTOR at $4{ }^{\circ} \mathrm{C}$.

Then, the membrane was rinsed two times with TBST, followed by incubation for $1 \mathrm{~h}$ with HRPconjugated $2^{\circ}$ antibodies at laboratory temperature. Visualization of the protein bands was achieved with ECL kit, while the relative abundance of expressions were determined with TM Imager 600 System, with $\beta$-actin as internal control.

\section{qRT-PCR}

Total RNA was extracted from tumor tissues using Trizol reagent, and the RNA contents were determined spectrophotometrically at $260 \mathrm{~nm}$. Following treatment of the extracted RNA with DNAase, it was reverse-transcribed to cDNA with PrimeScript $^{\mathrm{TM}}$ Reverse Transcription kit bearing gDNA Eraser kit (Takara, China).

The cDNA product was used as template for quantitative PCR which was carried out using ABI 7500 RT-PCR system. The sequence of primers used are indicated in Table 1. The relative mRNA expressions were calculated with the $2^{-\Delta \Delta}$ CT procedure, with $\beta$-actin as reference gene.
Table 1: Primer sequences used for real-time quantitative polymerase chain reaction

\begin{tabular}{lll}
\hline Gene & Forward (5 '-3 ') & Reverse (5-3') \\
\hline Bcl-2 & GGTGGGGTCATGT & CGGTTCAGGTACT \\
& GTGTGG & CAGTCATCC \\
Bax & CCCGAGAGGTCTT & CCAGCCCATGATG \\
& TTTCCGAG & GTTCTGAT \\
Casp & CATGGAAGCGAAT & CTGTACCAGACCG \\
ase-3 & CAATGGACT & AGATGTCA \\
$\beta-$ & AGAAAATCTGGCA & TAGCACAGCCTGG \\
actin & CCACACC & ATAGCAA \\
\hline
\end{tabular}

\section{Statistical analysis}

Results are presented as SD. Statistical analysis was done with ANOVA and thereafter with Dunnett's test using GraphPad Prism ver 6.0 software. Values of $p<0.05$ were assumed to be statistically significant.

\section{RESULTS}

Inhibitory influence of Tanshinone IIA on proliferative potential of $\mathbf{J} 82$ cells

Treatment with T11A markedly suppressed J82 cell growth in a dose-based fashion, with $80 \mu \mathrm{g} / \mathrm{ml}$ Tanshinone IIA producing about 56.79 $\%$ growth inhibition (Figure 1).

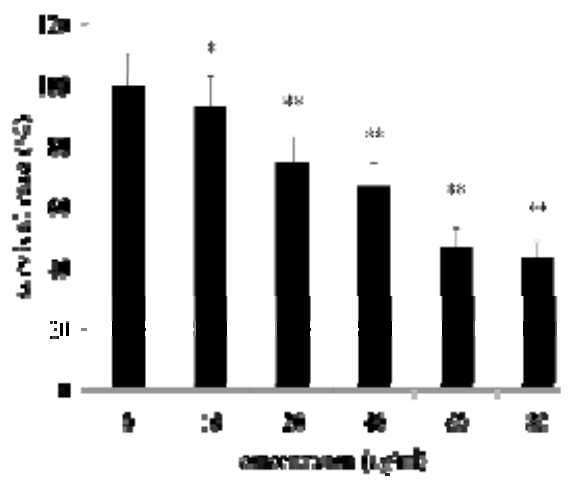

Figure 1: Effect of TIIA on J82 cell survival (\%); * $p<$ $0.05 ;{ }^{* *} p<0.01$, vs control

\section{Influence of tanshinone IIA on $\mathrm{PI} 3 \mathrm{~K} / \mathrm{AKT} / \mathrm{mTOR}$ signal route in $\mathrm{J} 82$ cells}

The effect of tanshinone IIA on the $\mathrm{PI} 3 \mathrm{~K} / \mathrm{AKT} / \mathrm{mTOR}$ pathway in J82 cells was studied. As presented in Figure 2, the ratios $\mathrm{PI} 3 \mathrm{~K} /$ Actin, $\mathrm{p}-\mathrm{AKT} / \mathrm{Actin}$, and $\mathrm{p}$-mTOR/actin were reduced in $\mathrm{J} 82$ cells after treatment with TIIA at doses of $40,80 \mu \mathrm{g} / \mathrm{mL}$ for $48 \mathrm{~h}$, indicating that TIIA inactivated the PI3K/AKT/mTOR route in J82 cells. 


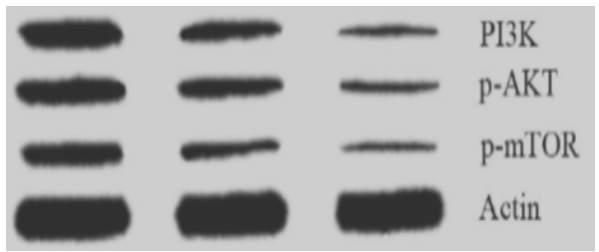

Figure 2: Effect of Tanshinone IIA on protein expressions of P-AKT, PI3K and p-mTOR

\section{Effect of tanshinone IIA on apoptotic genes in J82 cells}

Real-time $\mathrm{qPCR}$ was used to validate the outcome of MTT experiments. The results indicated that, relative to control, the T11Atreated cells had reduced $\mathrm{Bcl}-2$ concentration and increased amounts of Bax and caspase- 3 . In addition, the effect of T11A was dose-dependent (Figure 3).

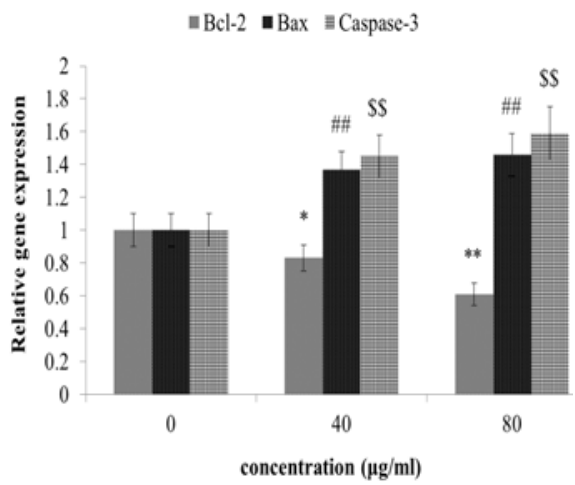

Figure 3: Effect of T11A on mRNA expressions of Bacl-2, Bax and caspase-3; ${ }^{*} p<0.05 ;{ }^{* *}, \ldots, \$ \$ p<0.01$, vs control

\section{DISCUSSION}

Globally, bladder carcinoma accounts for the $7^{\text {th }}$ most frequent malignancy in males, and the $17^{\text {th }}$ most occurring carcinoma in females [12]. The disease affects various tissues of the urinary bladder. More than $70 \%$ of fresh cases of bladder carcinoma are non-invasive, with high frequency of recurrence, notwithstanding localized treatment [12]. In addition, in spite of systemic treatment, the prognosis of about $25 \%$ of new cases with metastasis to the muscle, is very poor [13]. However, not much is known about the etiology of bladder carcinoma.

Over the years, several studies on the phytochemical components of S. miltiorrhiza have led to the isolation and identification of more than 80 compounds, some of which comprise lipophilic diterpenoids [14]. The predominant lipophilic compounds are TIIA, TIIB,
$\mathrm{TI}$, and cryptotanshinone, with TIIA being the most prevalent [15].

Tanshinone 11A (T11A) exerts several pharmacological effects such as suppression of platelet aggregation, inhibition of inflammation, antioxidation and anti-carcinogenic properties $[16,17]$. In this study, T11A markedly reduced the viability of $\mathrm{J} 82$ cells.

The PI3K/AKT/mTOR signal route is involved in suppression of apoptosis [18]. In this pathway, P13K activates AKT through phosphorylation, thereby converting it to p-AKT [19]. In turn, pAKT activates a series of downstream factors, including mTOR [20]. Through mTOR, p-AKT controls proliferative potential and growth of cells.

In this investigation, Tanshinone IIA markedly downregulated mTOR, AKT and P13K, as well as their activated forms, thereby suppressing the $\mathrm{PI} 3 \mathrm{~K} / \mathrm{AKT} / \mathrm{mTOR}$ signaling route. Thus, caspase3 and $\mathrm{Bax}$ were upregulated, while $\mathrm{Bcl}-2$ was suppressed, leading to cell death.

\section{CONCLUSION}

The present study has presented evidence that tanshinone IIA acts as an anti-tumor drug in bladder cancer in vitro. It IIA kills tumour cell J82 probably by suppressing the PI3K/AKT/mTOR signal route. This new finding on the inhibitory effect of tanshinone IIA suggests that it is a potential therapeutic strategy against bladder cancer.

\section{DECLARATIONS}

\section{Conflict of interest}

No conflict of interest is associated with this work.

\section{Contribution of authors}

We declare that this work was done by the authors named in this article and all liabilities pertaining to claims relating to the content of this article will be borne by the authors. Xianjun Zhang, Ziwen Lu designed all the experiments and revised the paper. Songzhe Piao and Tao Hong wrote the manuscript.

\section{Open Access}

This is an Open Access article that uses a funding model which does not charge readers or their institutions for access and distributed under the terms of the Creative Commons Attribution 
License (http://creativecommons.org/licenses/by/ 4.0) and the Budapest Open Access Initiative (http://www.budapestopenaccessinitiative.org/rea d), which permit unrestricted use, distribution, and reproduction in any medium, provided the original work is properly credited.

\section{REFERENCES}

1. Zhou ZH, Weng Q, Zhou JH, Zhou J. Extracts of Salvia miltiorrhiza Bunge on the cytokines of rat endometriosis models, Afr. J. Tradit. Complement. Altern. Med. 2012; 9 (3): 303-314.

2. Peng $T M$, Jiang $Y Z$, Farhan $M$, Lazarovici $P$, Chen $L G$, Zheng WH. Anti-inflammatory effects of traditional Chinese medicines on preclinical in vivo models of brain ischemia-reperfusion-injury: prospects for neuroprotective drug discovery and therapy, Front. Pharmacol. 2019; 10: 204.

3. Liu S, Wang $K H$, Duan $X J$, Wu JR, Zhang $D$, Liu $X K$, Zhao $Y$. Efficacy of danshen class injection in the treatment of acute cerebral infarction: a bayesian network meta-analysis of randomized controlled trials, Evid. Based Complement. Alternat. Med. 2019; 3: 5814749.

4. Yu ML, Li SM, Gao X, Li JG, Xu H, Chen KJ. Sodium Tanshinone II a Sulfonate for coronary heart disease: a systematic review of randomized controlled trials, Chin. J. Integr. Med. 2018; 11 (10): 018-2556.

5. Li XJ, Li ZF, Li XP, Liu BG, Liu ZJ, Mechanisms of Tanshinone II a inhibits malignant melanoma development through blocking autophagy signal transduction in A375 cell, BMC Can. 2017; 17: 357.

6. Gong G, Gu Y, Zhang Y, Liu W, Li L, Li J. Tanshinone IIA alleviates oxidative damage after spinal cord injury in vitro and in vivo through up-regulating miR-124, Life Sci. 2019; 216:147-155.

7. Luan L, Liang $Z$. Tanshinone IIA protects murine chondrogenic ATDC5 cells from lipopolysaccharideinduced inflammatory injury by down-regulating microRNA- 203a, Biomed. Pharmacother. 2018; 103: 628-636.

8. Morgan TM, Clark PE. Bladder cancer. Curr Opin Oncol 2010; 22: 242.

9. Shariat SF, Karam JA, Lotan Y, Karakiewizc PI. Critical evaluation of urinary markers for bladder cancer detection and monitoring. Rev Urol 2008; 10: 120-135.
10. Li K, Lin T, Chinese Bladder Cancer C, Xue W, Mu X, Xu $E$, Yang $X$, Chen FB, Li GY, Ma LL, et al. Current status of diagnosis and treatment of bladder cancer in China analyses of Chinese Bladder Cancer Consortium database, Asian J. Urol. 2015; 2 (2): 63-69.

11. Pang C, Guan Y, Li H, Chen W, Zhu G. Urologic cancer in China, Jpn. J. Clin. Oncol. 2016; 46 (6): 497-501.

12. Feigin V. Global, regional, and national incidence, prevalence, and years lived with disability for 310 acute and chronic diseases and injuries, 1990-2015: a systematic analysis for the global burden of disease study 2015, Lancet (London, England) 2016; 386 (9995): 743.

13. Babjuk $M$, Burger $M$, Zigeuner $R$, Shariat $S F$, van Rhijn $B W$, Compérat E, Sylvester RJ, Kaasinen E, Böhle A, Palou RJ. EAU guidelines on non-muscle invasive urothelial carcinoma of the bladder: update 2013, Eur. Urol. 2008; 54 (2): 303.

14. Wang $X$, Morris-Natschke SL, Lee KH. New developments in the chemistry and biology of the bioactive constituents of Tanshen, Med. Res. Rev. 2007; 27 (1): 133-148.

15. S Gao et al. Cardiovascular actions and therapeutic potential of tanshinone IIA, Atherosclerosis 220 (1) (2012) 3-10.

16. Maione F, De Feo V, Caiazzo E, De Martino L, Cicala C, Mascolo N, et al., Tanshinone IIA, a major component of Salvia milthorriza Bunge, inhibits platelet activation via Erk-2 signaling pathway, J. Ethnopharmacol. 2014; 155 (2):1236-1242.

17. Liu F, Yu G, Wang GJ, Liu HY, Wu XL, Wang Q, Liu M, Liao K, Wu MQ, Cheng XF, et al., An NQO1-initiated and p53-independent apoptotic pathway determines the anti-tumor effect of tanshinone IIA against non-small cell lung cancer, PLoS One. 2012; 7 (7): 27

18. Yao $H, \operatorname{Han} X, \operatorname{Han} X$. The cardioprotection of the insulinmediated PISK/AKt/mTOR signaling pathway. Am. J. Cardiovasc. Drugs; 2014. 14 (6): 433-442.

19. Manfredi GI, Dicitore A, Gaudenzi G, Caraglia M, Persani $L$, Vitale G. PIJK/Akt/mTOR signaling in medullary thyroid cancer: a promising molecular target for cancer therapy. Endocrine 2015; 48 (2): 363-370.

20. Ruicci KM, Plantinga $P$, Pinto $N$, Khan MI, StechoW, Dhaliwal SS, Yoo J, Fung K, MacNeil D, Mymryk JS, et al. Disruption of the RICTOR/mTORC2 complex enhances the response of head and neck squamous cell carcinoma cells to PI3K inhibition. Mol Oncol. 2019; 13 (10): 2160-2177. 